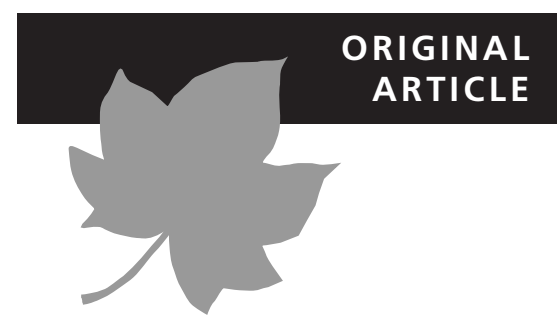

\title{
Prehistoric anthropogenic introduction of partulid tree snails in Papua New Guinean archipelagos
}

Diarmaid Ó Foighil ${ }^{1 \star}$, Taehwan Lee ${ }^{1}$ and John Slapcinsky ${ }^{2}$

${ }^{1}$ Museum of Zoology and Department of Ecology and Evolutionary Biology, University of Michigan, Ann Arbor, MI 48109-1079, USA, ${ }^{2}$ Florida Museum of Natural History and Department of Zoology, University of Florida, Gainesville, FL 32611, USA
${ }^{\star}$ Correspondence: Diarmaid Ó Foighil, Museum of Zoology and Department of Ecology and Evolutionary Biology, University of Michigan, Ann Arbor, MI 48109-1079, USA.

E-mail: diarmaid@umich.edu

\section{ABSTRACT}

Aim Members of the tropical tree snail family Partulidae are endemic to Pacific high oceanic islands and typically have single-island ranges. Two nominal Papua New Guinean species, Partula carteriensis and Partula similaris, deviate from familial norms by having extensive multi-island ranges that include low islands. We hypothesized that undocumented anthropogenic introductions may underlie this regional biogeographical anomaly and evaluated this hypothesis with novel field distributional and genotypic data.

Location Papua New Guinean archipelagos between 1.4 and $11.4^{\circ} \mathrm{S}$ and 146.5 and $154.2^{\circ} \mathrm{E}$.

Methods Ethanol-preserved museum lots of P. carteriensis (from New Britain, Bismarck Archipelago) and P. similaris (from Woodlark, Boiaboiawaga and Goodenough islands) were genotyped for a standard mitochondrial marker, cytochrome $c$ oxidase subunit I (COI), and the resulting haplotypes were subjected to phylogeographical analyses.

Results All four genotyped populations showed very little genetic or conchological differentiation, irrespective of nominal taxonomic status, the archipelago sampled or whether the island was low, high, oceanic or continental. Partula carteriensis and P. similaris exhibit atypical distributions on larger high islands, being restricted to coastal villages and absent from native forest.

Main conclusions Our results strongly indicate that $P$. carteriensis and $P$. similaris are conspecific, although a formal taxonomic revision is beyond the scope of this present study. They collectively exhibit the most heterogeneous geographical range known among partulids and their explicitly synanthropic association with high island coastal villages strongly implicates human introduction as the regional dispersal mechanism. We currently lack insights into the timeframe (apart from regional prehistory) and cultural context of these translocations. We also lack a convincing source population, and it may be necessary to survey the partulid fauna of the neighbouring Solomon Islands to identify one. Partulids are critically endangered throughout much of their range and the discovery of populations that apparently thrive in human-altered landscapes is noteworthy. Their study may provide clues of broad relevance to partulid conservation.

\section{Keywords}

Melanesia, museum collections, Pacific Islands, Partula, prehistoric exchange networks, tree snails. 


\section{INTRODUCTION}

The Pacific island tree snail family Partulidae exhibits a distinctive biogeography: members are endemic to tropical oceanic high islands, i.e. non-continental islands of hotspot or arcuate volcanic origin with sufficient elevation to generate their own precipitation and support rain forest formation (Craig, 2003; Gillespie et al., 2008). Although individual snails rarely disperse more than a few metres during their lives
(Murray \& Clarke, 1984), partulids have attained a spectacular collective range spanning $>10,000 \mathrm{~km}$ of Oceania from Belau and the Marianas in the north-west to the Marquesas, Austral and Society Islands in the south-east (Cowie, 1992).

This pattern of distribution is necessarily a product of oceanic dispersal (Cowie \& Holland, 2006). Indeed, because most partulid species occur on hotspot archipelagos in which high islands are transient geological entities (Neall \& Trewick, 2008), tree snail lineages in these chronologically arrayed island chains

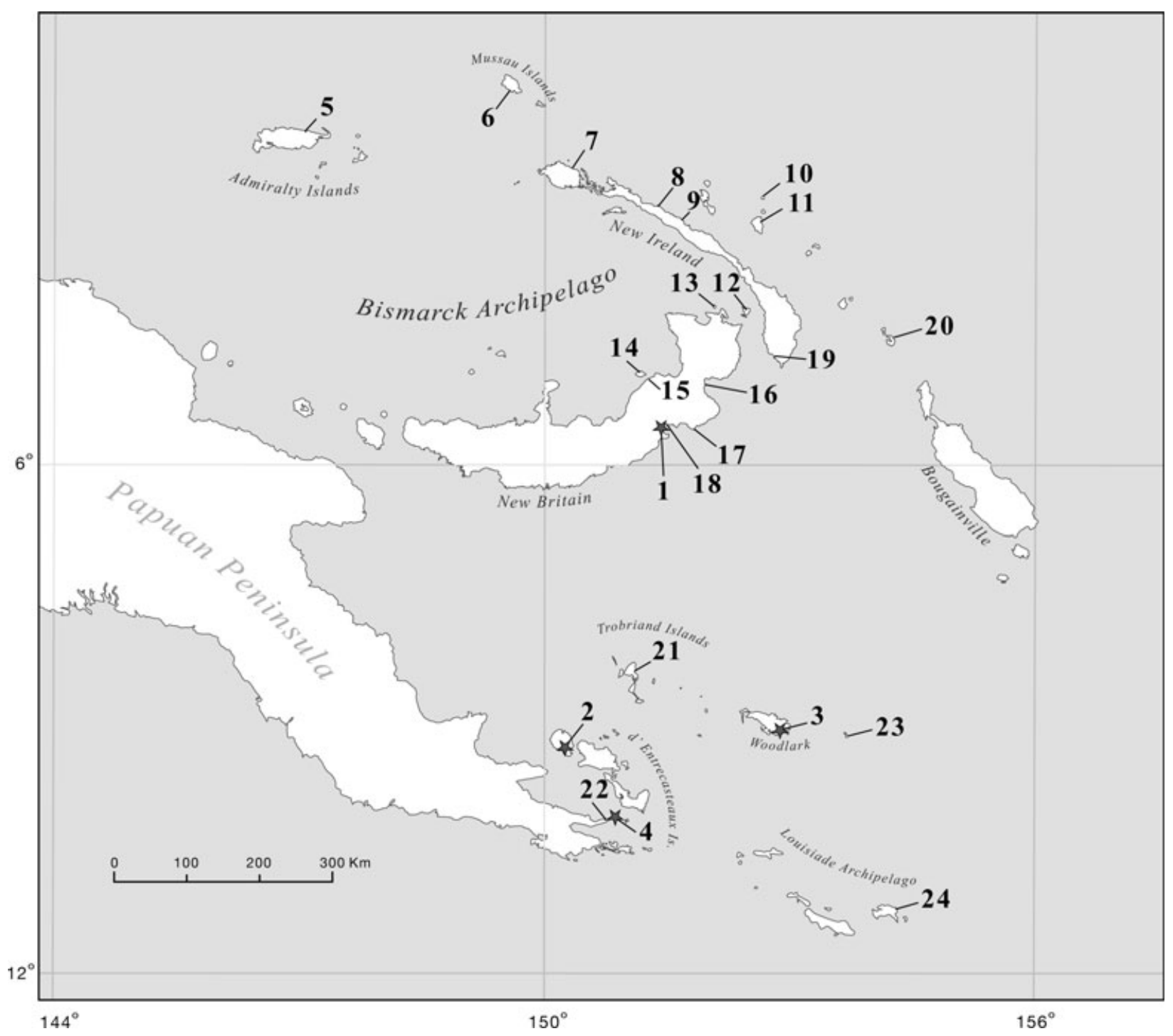

Figure 1 Map of the study area of Papua New Guinean archipelagos. Genotyped study populations of partulid tree snails are indicated with star symbols and are numbered as follows: 1, three adjacent New Britain Partula carteriensis populations from near Pomio, New Britain; 2, Wailagi, Goodenough Island P. similaris; 3, Guasopa, Woodlark (Muyua) Island P. similaris; 4, Boiaboiawaga Island P. similaris. Locations 5-18 show Rensch's (1937) P. carteriensis distribution records: 5, Manus Island; 6, Mussau/St Matthias; 7, New Hanover/ Neu-Hannover; 8, 9, Medina and Lamassong, respectively, both on New Ireland/Neu-Mecklenberg; 10, Mahur; 11, Lihir; 12, Duke of York Islands/Neu-Lauenburg; 13, Watom/Vuatom; 14, Lolobau; and four locations on New Britain/Neu-Pommern (15, Ulamona; 16, Jacquinot Bay/Jacquinobucht; 17, Makong; 18, Wide Bay/Weide Bucht). Location 19 is Port Carteret, the type locality of P. carteriensis and Dell (1955) also recorded it in location 20, Nissan Island. In addition to the three genotyped P. similaris populations (2, 3, 4), this species has also been recorded from the following locations: 21, Trobriand Islands (Pilsbry, 1909-1910); 22, Iburai/Ibulai on the PNG mainland, $10^{\circ} 13^{\prime} 58.8^{\prime \prime}$ S, $150^{\circ} 49^{\prime} 59.88^{\prime \prime}$ E (Clench, 1936); 23, Laughlan Islands, Australian Museum No. C.222179; 24, Rossel (Yela) Island, Australian Museum No. C.779. 
must have experienced repeated among-island dispersal events during their evolutionary histories. The mechanisms of oceanic island land snail dispersal are speculative, although aerial transport is usually favoured over rafting (Vagvolgyi, 1976; Peake, 1981; Gittenberger et al., 2006). However, we can infer that successful partulid inter-island dispersal events are rare because the large majority of species, e.g. 59 of the 61 described Society Islands taxa (Kondo, 1968) are single island endemics.

A small number of partulid species breach familial biogeographical norms in that they occur on multiple geographically disjunct islands, including some of low relief. The best-studied exception is Partula hyalina Broderip, 1832, the only partulid known to have a multi-archipelago distribution (Pilsbry, 19091910; Cooke, 1928). Genetic characterization of this species in the Society, Austral and Cook archipelagos identified Tahiti as the source island and implicated prehistoric Polynesian interarchipelago human exchange networks as the dispersal mechanism (Lee et al., 2007a). This present study examines the biogeographical relationships of two additional species of Partula that exhibit anomalous distributions. They occur at the south-western limit of the familial distribution, the island archipelagos of Papua New Guinea (PNG), and have been relatively unstudied since the 1930s.

Partula carteriensis (Quoy \& Gaimard, 1832) has an extensive multi-island distribution throughout the Bismarck Archipelago where it occurs on both high and low islands (see Fig. 1; Rensch, 1937; Dell, 1955). Partula similaris Hartman, 1886 was originally described as a Woodlark Island endemic but there are also records for the species from the Trobriand Islands (Pilsbry, 1909-1910) and from the East Cape peninsula of mainland PNG (Clench, 1936). The latter report is notable for being the only reliable record of an unambiguously continental partulid population. The geographical area occupied by these two species is geologically complex (Hill \& Raza, 1999) and constituent islands may have diverse geological histories that include continental, volcanic or composite accretion/subduction origins.

In his description of $P$. similaris, Hartman (1886) commented on its conchological similarity to P. carteriensis. Rensch (1937) performed the most recent in-depth study on regional PNG partulids but, being constrained to former German colonial territories (north-eastern PNG, Bismarck and Admiralty Islands), she did not include $P$. similaris. We genotyped museum samples of both nominal species to test their inter-relationships and our molecular data strongly indicate that they are conspecific. This result, together with the synanthropic distribution patterns exhibited by these snails on regional high islands, implicates a central role for anthropogenic introduction in their collective multi-archipelagic range.

\section{MATERIALS AND METHODS}

\section{Sampling}

All samples employed in this study were from museum collections. To examine shell phenotype variation, dried museum lots of $P$. carteriensis and $P$. similaris were obtained from a number of institutions including the Australian Museum (Sydney, Australia), the Museum of Comparative Zoology (Harvard, USA), the Field Museum of Natural History (Chicago, USA) and the Carnegie Museum of Natural History (Pittsburgh, USA).

In total, 59 ethanol-preserved museum specimens, comprising 27 of $P$. carteriensis and 32 of $P$. similaris, were successfully genotyped (Table 1). The former species was sampled in 2005 by J.S. from three adjacent East New Britain Province locations and deposited as separate lots in the Florida Museum of Natural History mollusc collection. Each New Britain sampling location was situated on the outskirts of a village, the snails being absent from adjacent native forest habitat (J.S., pers. obs.). Lot UF 366477 (12 specimens genotyped) was obtained from Marmar Village $\left(5.5183^{\circ} \mathrm{S}, 151.5067^{\circ} \mathrm{E}\right), 1 \mathrm{~km}$ west of the town of Pomio, in hill forest and garden habitat at an elevation of $20 \mathrm{~m}$. Lot UF 366509 (eight specimens genotyped) was from Ulege Village $\left(5.5173^{\circ} \mathrm{S}, 151.5007^{\circ} \mathrm{E}\right), 1 \mathrm{~km}$ west of Marmar Village, taken in secondary hill forest and gardens at an elevation of $140 \mathrm{~m}$. The third New Britain lot (UF 366510; seven specimens genotyped) was sourced from along the west bank of the Pomio River $\left(5.5153^{\circ} \mathrm{S}, 151.5111^{\circ} \mathrm{E}\right), 1 \mathrm{~km}$ east of Marmar Village, in secondary hill forest from an elevation of 0-65 m.

Ethanol-preserved $P$. similaris samples were genotyped from three island populations. Lot UF 303731 (18 specimens genotyped) was sampled in 2003 by J.S. from Woodlark (Muyua) Island, its type locality. The snails occurred on coastal forest and hibiscus thicket vegetation (elevation $5 \mathrm{~m}$ ) around the village of Guasopa $\left(9^{\circ} 13.444^{\prime} \mathrm{S}, 152^{\circ} 56.637^{\prime} \mathrm{E}\right)$. As in New Britain, snails were encountered on the perimeter of the village but not observed in the adjacent native forest (J.S., pers. obs.). Lot UF 303716 (13 specimens genotyped) was collected in 2002 by F. Kraus (Bishop Museum, Honolulu, HI, USA) on Boiaboiawaga Island $\left(10^{\circ} 12^{\prime} 33^{\prime \prime} \mathrm{S}, 150^{\circ} 54^{\prime} 20^{\prime \prime} \mathrm{E}\right)$. This is a tiny (c. $8 \mathrm{ha}$ ) islet situated $3.5 \mathrm{~km}$ off the tip of the East Cape peninsula (Milne Bay Province) of PNG. The snails occurred in the centre of the islet (elevation $5 \mathrm{~m}$ ) in dense Pisonia grandis cover (F. Kraus, pers. comm.). A single shell-less specimen (UMMZ 302228) of presumed P. similaris from Goodenough Island (D'Entrecastreux Group, Milne Bay Province, PNG) was also genotyped. It was collected by J. B. Burch (University of Michigan, Ann Arbor, MI, USA) in 1966 on the outskirts of Wailagi $\left(9^{\circ} 34^{\prime} 40^{\prime \prime} \mathrm{S}, 150^{\circ} 20^{\prime} 14^{\prime \prime} \mathrm{E}\right)$, a coastal village on Wailagi Bay in the south-east of the island.

\section{Molecular and phylogenetic methods}

Total genomic DNA was isolated using the EZNA ${ }^{\circledR}$ Mollusc DNA Kit (Omega Bio-tek, Norcross, GA, USA) or the DNeasy Kit (Qiagen Inc., Valencia, CA, USA) following the manufacturers' instructions. A 655-nucleotide (nt) mitochondrial (mt) cytochrome $c$ oxidase subunit I (COI) target fragment was amplified with GoTaq DNA Polymerase (Promega, Madison, WI, USA) using the 'universal' (Folmer et al., 1994) primer pair LCO1490/HCO2198 and a negative control (no template) 


\begin{tabular}{llllll}
\hline & & $\begin{array}{l}\text { No. of } \\
\text { locations } \\
\text { sampled }\end{array}$ & $\begin{array}{l}\text { No. of } \\
\text { snails } \\
\text { sequenced }\end{array}$ & $\begin{array}{l}\text { No. of } \\
\text { haplotypes } \\
\text { obtained }\end{array}$ & GenBank accession number \\
\hline $\begin{array}{l}\text { P. carteriensis } \\
\begin{array}{l}\text { P. similaris } \\
\text { New Britain }\end{array}\end{array}$ & 3 & 27 & 4 & HQ230002-HQ230010 \\
& Woodlark & 1 & 18 & 2 & HQ22999-HQ230001 \\
& Goodenough & 1 & 1 & 1 & HQ229996 \\
& Boiaboiawaga & 1 & 13 & 2 & HQ229997, HQ229998 \\
\hline
\end{tabular}

Table 1 Taxonomic identity of partulid tree snails (Partula carteriensis and P. similaris) genotyped in this study, together with the number of sampling locations from Papua New Guinea, individuals sequenced, haplotypes recovered per island, and GenBank accession numbers. was included in each amplification run. After 2 min denaturation at $95{ }^{\circ} \mathrm{C}$, an initial annealing temperature of $53{ }^{\circ} \mathrm{C}$ was decreased by $1{ }^{\circ} \mathrm{C} / \mathrm{cycle}\left(30 \mathrm{~s}\right.$ denaturing at $95^{\circ} \mathrm{C}, 40 \mathrm{~s}$ annealing and $1 \mathrm{~min}$ extension at $72^{\circ} \mathrm{C}$ ) until the final annealing temperature $\left(45^{\circ} \mathrm{C}\right)$ was reached and subsequently maintained for an additional 30 cycles. Polymerase chain reaction (PCR) products were prepared for cycle sequencing by diluting them 1:5 in sterile water. Both strands of the amplified fragments were directly sequenced, using the PCR primers, at the University of Michigan's Sequencing Core Facility. The resulting chromatograms were edited using SEQUencher 4.8
(Gene Codes Corporation, Ann Arbor, MI, USA) and the sequences obtained have been deposited in GenBank (Table 1). A parsimony network was constructed using the statistical parsimony (Templeton et al., 1992) method in TCS 1.21 (Clement et al., 2000) employed with a 90\% connection limit.

\section{RESULTS}

A total of eight haplotypes were recovered, four from each taxon. Figure 2 graphically presents a genealogical assessment of New Britain P. carteriensis haplotypes together with those of

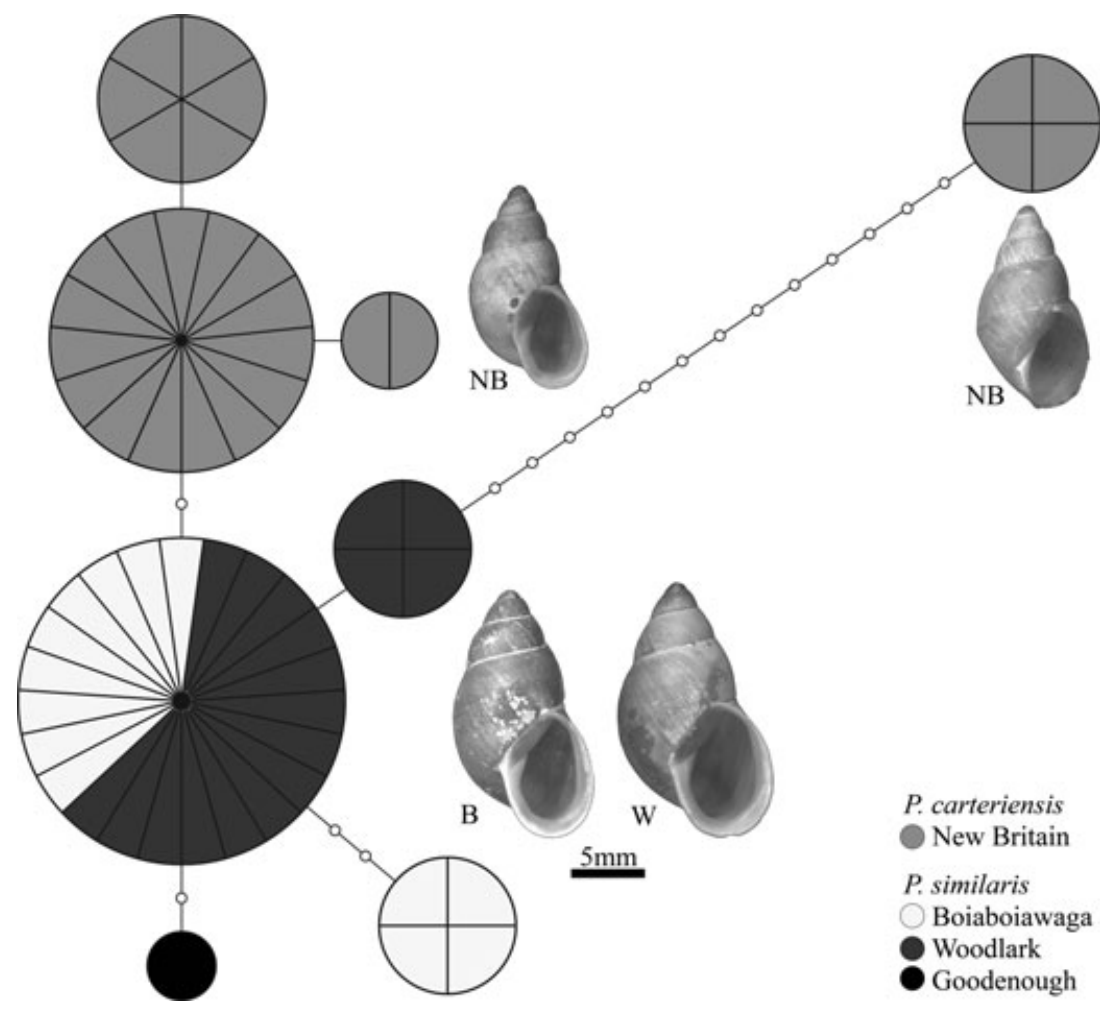

Figure 2 Statistical parsimony network of the eight mitochondrial cytochrome $c$ oxidase subunit I (COI) haplotypes (655-nucleotide fragments) obtained from the $27 \mathrm{New}$ Britain Partula carteriensis and the 32 P. similaris tree snails (18 from Woodlark, 13 from Boiaboiawaga and 1 from Goodenough) genotyped for this study. Each terminal circle represents a single COI haplotype, sized according to its relative abundance, and shaded to reflect the island(s) that the snails bearing it were sampled from (see key). Branches connecting the haplotype circles are scaled to reflect the number of inferred substitutions separating them with smaller unlabelled circles representing inferred 'missing' intermediate haplotypes. Exemplar shell phenotypes, all at the same magnification (see common $5 \mathrm{~mm}$ scale bar) are shown. The Woodlark (W) and Boiaboiawaga (B) snails depicted both had the most common P. similaris haplotype. Note that two exemplar shells are shown for the New Britain P. carteriensis sample. One depicts the adult phenotype associated with the modal COI haplotypic cluster (top left), the other (top right) shows the immature shell phenotype exhibited by the four New Britain snails bearing the divergent COI haplotype. 

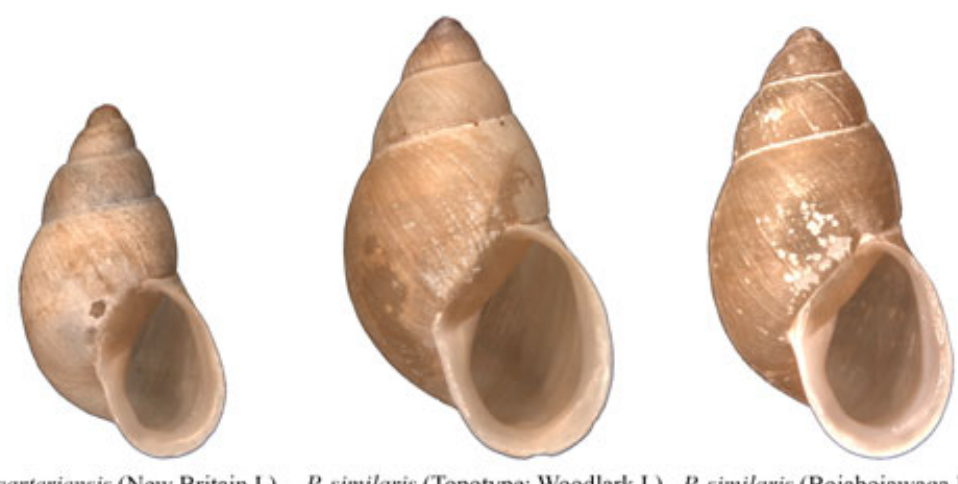

P. carteriensis (New Britain L.) P. similaris (Topotype: Woodlark L.) P. similaris (Boiaboiawaga L.)
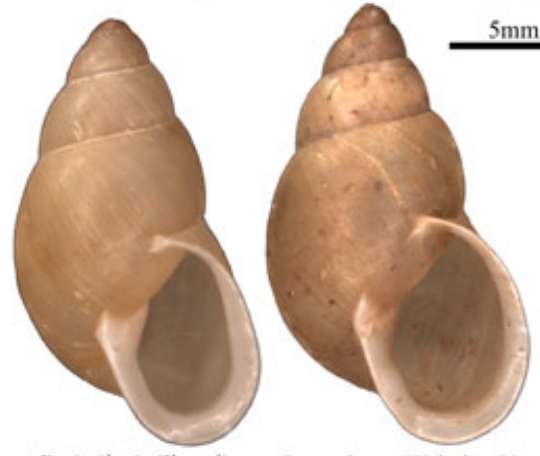

P. similaris (Kiriwina I.)
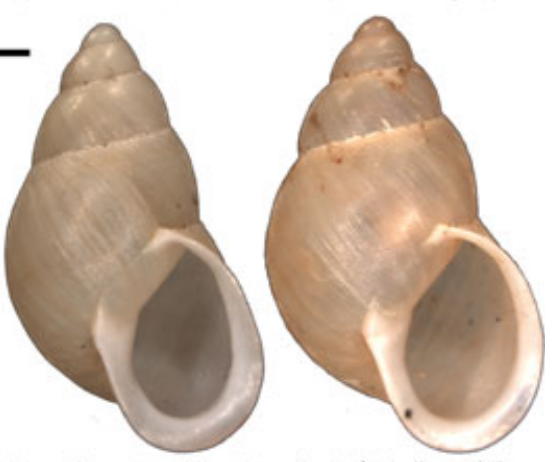

Figure 3 Exemplar shell phenotypes, all at the same magnification, for three of our four genotyped Partula populations (top row) in addition to specimens of P. similaris from Iburai/Ibulai, East Cape, Papua New Guinea mainland (MCZ 111154), Kiriwina Island, Trobriand Group (Australian Museum No. 22179), Laughlan Islands (Australian Museum No. C.222179) and Rossel (Yela) Island, Louisade Archipelago (Australian Museum No. C.779).

P. similaris from Woodlark, Boiaboiawaga and Goodenough islands. The most striking feature of these data is the lack of genetic differentiation separating the two taxa. For instance, the most common (modal) P. carteriensis haplotype $(n=15)$ differs from the modal $P$. similaris haplotype $(n=23)$ by two inferred substitutions. This is less than the within-population variation exhibited by $P$. similaris on the 8 -ha islet of Boiaboiawaga (three inferred substitutions) and it is much less than the 17-18 inferred substitutions (c. 3\% sequence divergence) separating the most distinct $P$. carteriensis haplotype from the three others present in the New Britain study populations. Another salient feature is the lack of genetic differentiation among geographically distant populations, e.g. the modal $P$. similaris haplotype predominates in our Boiaboiawaga $(n=9)$ and Woodlark $(n=14)$ samples although these two islands are $>200 \mathrm{~km}$ apart.

We could not identify any conchological character that unambiguously distinguished the two taxa. Specimens of P. similaris from Woodlark and Boiaboiawaga islands differ from New Britain P. carteriensis snails only in being larger in mean size (Fig. 2). The New Britain snails did exhibit subtle within-population variation in shell phenotype maturation that may be correlated with mitochondrial haplotype diversity. Shell growth in partulids is determinate, with adulthood being marked by the formation of a flared lip at the shell aperture (Cowie, 1992). All four P. carteriensis snails bearing the divergent mitochondrial haplotype lacked this feature, although co-occurring similar-sized conspecifics bearing modal mitochondrial haplotypes had the adult apertural condition (Fig. 2). Our genotyped populations of both nominal taxa overlapped conchologically with museum samples of P. similaris from the Laughlan Islands, Trobriand Islands, Iburai/Ibulai on the PNG mainland and Rossel (Yela) Island in the Louisade Archipelago (Fig. 3).

\section{DISCUSSION}

Our results strongly indicate that $P$. carteriensis and $P$. similaris are conspecific, although a formal taxonomic revision is beyond the scope of this present study. A striking aspect of their collective distribution is presence on island groups that have very distinct geological histories. Indeed, it encompasses one of the most complex tectonic regions on the planet, including the northern edge of the Australian Plate (southern Papuan Peninsula and the Louisiade Archipelago) and up to five micro-plates: the Woodlark Plate (Woodlark, Trobriand and Goodenough islands, East Cape Peninsula PNG) Solomon Sea Plate, South Bismarck Plate (New Britain), Manus Plate and North Bismarck Plate (New Ireland, Mussau and Admiralty islands) (Bird, 2003). These island groups have also experienced distinct patterns of inter-connectivity during glacial maxima when the Bismarck Archipelago and Woodlark 
Island were not connected to PNG, but the Trobriand and D'Entrecasteux islands were, thereby forming part of Sahul, the Pleistocene-era continent that combined present-day New Guinea with Australia and Tasmania (Voris, 2000).

The primary island groups inhabited by $P$. carteriensis and $P$. similaris are rich in endemic non-partulid land snail species that are restricted to particular islands (Hedley, 1891; Rensch, 1934, 1937; Iredale, 1941; Kraus et al., 2005; Slapcinsky, 2006) and lack the extensive ranges of our study taxa. A geographically extensive pattern of low island and coastal high island distribution is emblematic of invasive land snail species in the Pacific - endemic snails typically now being confined to the interior of high islands - (Cooke, 1928; Peake, 1969). Partula carteriensis and $P$. similaris fit the invasive land snail distribution profile; they collectively occur on many low islands (e.g. Boiaboiawaga, Samarai, Duke of York Islands etc.) in addition to larger high islands (e.g. New Britain, New Ireland and Goodenough etc.). Tellingly, all of Rensch's (1937) New Britain $P$. carteriensis records were from coastal locations (Fig. 1). This pattern was corroborated and extended by more recent field surveys that encountered this species on the outskirts of coastal villages/small towns on the island but not in native forest, either coastal or interior montane (Slapcinsky \& Lasley, 2007). A similar coastal village-centric pattern of distribution was observed for $P$. similaris on Woodlark Island (J.S., this study) and may also occur on Rossel Island where $P$. similaris was not encountered during land snail surveys of interior native forest (Slapcinsky, 2006). The sole records of $P$. similaris from Goodenough Island (J. B. Burch, this study) and from the PNG main island (Clench, 1936) are also from coastal villages: respectively, Wailagi and Iburai/Ibulai. Although we lack information from interior sites on Goodenough, the snail appears to be absent from interior East Cape Peninsula forests (Slapcinsky, 2005). This synanthropic pattern of distribution on the larger islands strongly implicates human introduction as the dispersal mechanism underlying the distinctive biogeography of $P$. carteriensis and $P$. similaris.

There are many well-documented cases of prehistoric human-introduced land snail species throughout Pacific archipelagos (Kirch \& Hunt, 1993; Kirch, 1996; Preece, 1998; Weisler, 1999). Almost all are exotic introductions of minute continental species that occur in association with introduced exotic food plants. For instance, Gastrocopta pediculus is c. $3 \mathrm{~mm}$ in size, occurs in nearly every inhabited atoll and high island in Oceania (Pilsbry, 1916-1918, p. 148), where it first appears in Polynesian (Kirch, 1973; Preece, 1998) and Micronesian (Weisler, 1999) archaeological strata, and is thought to have been inadvertently introduced in association with cultigen rootstock carried by early human colonists (Weisler, 1999). In contrast, the endemic Tahitian partulid $P$. hyalina may have been deliberately introduced to neighbouring archipelagos due to its perceived aesthetic ornamental value (Lee et al., 2007a). Although we conclude that $P$. carteriensis and $P$. similaris probably achieved their atypical geographical ranges through human agency, we currently lack sufficient data to infer the probable timeframe (apart from pre-dating the 1827 visit of the Astrolabe expedition; Quoy \& Gaimard, 1832), directionality and cultural context of these translocations.

Humans have lived on the Bismarck Archipelago for at least 36,000 years (Allen, 1996) and extensive exchange networks have inter-connected regional island groups since at least $3300 \mathrm{yr}$ в with the first appearance of the Lapita cultural complex, characterized by a distinctive dentate-stamped pottery (Kirch, 2000; Summerhayes, 2001). Intriguingly, the earliest Lapita sites in the Bismarck Archipelago are predominantly located on small offshore islands (e.g. the first record is from Watom Island; Meyer, 1909) and in coastal regions of larger islands (Specht, 2007), a distribution pattern that matches that of our two nominal study taxa (Fig. 1). Land snails have been recovered from Lapita archaeological sites in the Bismarck Archipelago (Weisler, 2001). However, they have not been parsed taxonomically, and we therefore cannot directly place either nominal species within a Lapita cultural context.

Regular inter-island and inter-archipelago exchange networks are thought to have been a critical aspect of prehistoric Pacific island societies (Irwin, 1992). Such networks can be reconstructed by identifying the source island/archipelago of a putatively translocated item. This can be achieved by geochemical analyses of stone tools (Collerson \& Weisler, 2007) and/or skeletal remains (Shaw et al., 2010), or by phylogeographical analyses of ancient and/or recent DNA samples (Matisoo-Smith \& Robins, 2004; Lee et al., 2007a; MatisooSmith et al., 2009). None of the four locations from which we have genotyped snails match our expectations of a source partulid population in that they are either a minute low island or a larger high island where the snails had a synanthropic distribution. Based on Partulidae norms, we anticipate that the source population(s) - if extant, as extensive recent extinction has occurred in this family (Cowie, 1992; Coote \& Loève, 2003; Lee et al., 2007b, 2009) - occurs in high island native forest habitat and that it is genetically inclusive of the putative founder populations of New Britain, Goodenough, Woodlark and Boiaboiawaga. We currently lack an obvious candidate source island within the known nominal ranges of $P$. carteriensis and P. similaris (Fig. 1), although further fieldwork may well uncover one. It may be necessary to extend the search to the neighbouring Solomon Islands, home to eight nominal endemic species of Partula (Kondo, 1968) that have been grouped conchologically (Pilsbry, 1909-1910) and anatomically (Rensch, 1937) with P. carteriensis. Identification of convincing source population(s) would outline the underlying prehistoric exchange networks, and might also provide inferences into the motivation of the prehistoric human vectors (Lee et al., 2007a).

\section{ACKNOWLEDGEMENTS}

Our thanks to Fred Kraus and John B. Burch for providing details of their sampling sites, to John Meghahan for help with the map figure, to Phil Colman for interpreting PNG place 
names, and to Carole Hickman and an anonymous referee for their critical input. We are also grateful to Alison Miller and Ian Loch (Australian Museum), Philippe Maestrati and Virginie Héros (Muséum Nationale d'Histoire Naturelle), Jochen Gerber (Field Museum of Natural History), Adam Baldinger (Museum of Comparative Zoology), Tim Pearce (Carnegie Museum) and Darryl Potter (Queensland Museum) for providing access to pertinent museum material. Fieldwork was supported by NSF award DEB-0103794 to F. Kraus and A. Allison as well as by the University of Florida Foundation, McGinty Endowment. Laboratory work was supported by NSF award OCE-0850025 to D.ÓF.

\section{REFERENCES}

Allen, J. (1996) The pre-Austronesian settlement of island Melanesia: implications for Lapita archaeology. Transactions of the American Philosophical Society, 86, 11-27.

Bird, P. (2003) An updated digital model of plate boundaries. Geochemistry Geophysics Geosystems, 4, 1027.

Clement, M., Posada, D. \& Crandall, K.A. (2000) TCS: a computer program to estimate gene genealogies. Molecular Ecology, 9, 1657-1660.

Clench, W.J. (1936) A new subspecies of Papuina with records of land mollusks from eastern Papua and associated islands. The Nautilus, 50, 53-54.

Collerson, K.D. \& Weisler, M.I. (2007) Stone adze compositions and the extent of ancient Polynesian voyaging and trade. Science, 317, 1907-1911.

Cooke, C.M. (1928) Notes on Pacific land snails. Proceedings Third Pan-Pacific Science Congress, Tokyo, 2, 2276-2284.

Coote, T. \& Loève, É. (2003) From 61 species to five: endemic tree snails of the Society Islands fall prey to an ill-judged biological control programme. Oryx, 37, 91-96.

Cowie, R.H. (1992) Evolution and extinction of Partulidae, endemic Pacific island snails. Philosophical Transactions of the Royal Society B: Biological Sciences, 335, 167-191.

Cowie, R.H. \& Holland, B.S. (2006) Dispersal is fundamental to biogeography and the evolution of biodiversity on oceanic islands. Journal of Biogeography, 33, 193-198.

Craig, D.A. (2003) Geomorphology, development of running water habitats, and evolution of black flies on Polynesian islands. BioScience, 53, 1079-1093.

Dell, R.K. (1955) The land Mollusca of Nissan Island, Solomon Islands. Pacific Science, 9, 324-331.

Folmer, O., Black, M., Hoeh, W., Lutz, R. \& Vrijenhoek, R. (1994) DNA primers for amplification of mitochondrial cytochrome $c$ oxidase subunit I from diverse metazoan invertebrates. Molecular Marine Biology and Biotechnology, 3, 294-299.

Gillespie, R.G., Claridge, E.M. \& Roderick, G.K. (2008) Biodiversity dynamics in isolated communities: interaction between natural and human-mediated processes. Molecular Ecology, 17, 45-57.

Gittenberger, E., Groenberg, D.S.J., Kokshoorn, B. \& Preece, R.C. (2006) Molecular trails for hitch-hiking snails. Nature, 439, 409.
Hartman, W.T. (1886) New species of Partula from the New Hebrides and Solomon Islands. Proceedings of the Academy of Natural Sciences of Philadelphia, 1886, 30-35.

Hedley, C. (1891) The land molluscan fauna of British New Guinea. Proceedings of the Linnean Society of New South Wales, 6, 67-116.

Hill, K.C. \& Raza, A. (1999) Arc-continent collision in Papua Guinea: constraints from fission track thermochronology. Tectonics, 18, 950-966.

Iredale, T. (1941) A basic list of the land Mollusca of Papua. The Australian Zoologist, 10, 51-94.

Irwin, G. (1992) The prehistoric exploration and colonisation of the Pacific. Cambridge University Press, Cambridge.

Kirch, P.V. (1973) Prehistoric subsistence patterns in the northern Marquesas Islands, French Polynesia. Archaeology and Physical Anthropology in Oceania, 8, 24-40.

Kirch, P.V. (1996) Late Holocene human-induced modifications to a central Polynesian island ecosystem. Proceedings of the National Academy of Sciences USA, 93, 5296-5300.

Kirch, P.V. (2000) On the road of the winds: an archaeological history of the Pacific Islands before European contact. University of California Press, Berkeley, CA.

Kirch, P.V. \& Hunt, T.L. (1993) The To'aga site: three millennia of Polynesian occupation in the Manu'a Islands, American Samoa. Contributions of the Archaeological Research Facility, No. 51. University of California, Berkeley, CA.

Kondo, Y. (1968) Partulidae: preview of anatomical revision. The Nautilus, 81, 73-77.

Kraus, F., Pratt, T. \& Slapcinsky, J. (2005) Wildlife resources survey of Rossel and Sudest Islands, Louisiade Archipelago, Milne Bay Province. Technical Report, Conservation International, Washington, DC.

Lee, T., Burch, J.B., Coote, T., Fontaine, B., Gargominy, O., Pearce-Kelly, P. \& Ó Foighil, D. (2007a) Prehistoric interarchipelago trading of Polynesian tree snails leaves a conservation legacy. Proceedings of the Royal Society B: Biological Sciences, 272, 2907-2914.

Lee, T., Burch, J.B., Jung, Y., Coote, T., Pearce-Kelly, P. \& Ó Foighil, D. (2007b) Tahitian tree snail mitochondrial clades survived recent mass-extirpation. Current Biology, 17, R502R503.

Lee, T., Burch, J.B., Coote, T., Pearce-Kelly, P., Hickman, C., Meyer, J.Y. \& Ó Foighil, D. (2009) Moorean tree snail survival revisited: a multi-island genealogical perspective. BMC Evolutionary Biology, 9, 204.

Matisoo-Smith, E. \& Robins, J.H. (2004) Origins and dispersals of Pacific peoples: evidence from mtDNA phylogenies of the Pacific rat. Proceedings of the National Academy of Sciences USA, 101, 9167-9172.

Matisoo-Smith, E., Hingston, M., Summerhayes, G., Robins, J., Ross, H.A. \& Hendy, M. (2009) On the rat trail in Near Oceania: applying the commensal model to the question of the Lapita colonization. Pacific Science, 63, 465-475.

Meyer, O. (1909) Funde prähistorischer töpferei und steinmesser auf Vuatom, Bismarck Archipelagen. Anthropos, 4, 215-252. 
Murray, J. \& Clarke, B. (1984) Movement and gene flow in Partula taeniata. Malacologia, 25, 343-348.

Neall, V.E. \& Trewick, S.A. (2008) The age and origin of the Pacific islands: a geological overview. Philosophical Transactions of the Royal Society B: Biological Sciences, 383, 32933308.

Peake, J.F. (1969) Patterns in the distribution of Melanesian land Mollusca. Philosophical Transactions of the Royal Society of London Series B, Biological Sciences, 255, 285-306.

Peake, J.F. (1981) The land snails of islands - a dispersalist's viewpoint. The evolving biosphere: chance, change and challenge (ed. by P.L. Forey), pp. 247-263. Cambridge University Press, Cambridge.

Pilsbry, H.A. (1909-1910) Manual of conchology, structural and systematic, Vol. 20, Caecilioides, Glessula and Partulidae. Academy of Natural Sciences, Philadelphia, PA.

Pilsbry, H.A. (1916-1918) Manual of conchology, structural and systematic, Vol. 24, Pupillidae. Academy of Natural Sciences, Philadelphia, PA.

Preece, R.C. (1998) Impact of early Polynesian occupation on the land snail fauna of Henderson Island, Pitcairn group (South Pacific). Philosophical Transactions of the Royal Society B: Biological Sciences, 353, 347-368.

Quoy, J.R.C. \& Gaimard, J.P. (1832) Voyage de découvertes de l'Astrolabe 1826-1829. Zoologie, Vol. 2. Tastu, Paris.

Rensch, I. (1934) Systematische und tiergeographische Untersuchungen über die Landschneckenfauna des Bismarck-Archipels. I. Archiv für Naturgeschichte, 3, 445-488.

Rensch, I. (1937) Systematische und tiergeographische Untersuchungen über die Landschneckenfauna des BismarckArchipels. II. Archiv für Naturgeschichte, 6, 526-644.

Shaw, B., Buckley, H., Summerhayes, G., Anson, D., Garling, S., Valentin, F., Mandui, H., Stirling, C. \& Reid, M. (2010) Migration and mobility at the Late Lapita site of ReberRakival (SAC), Watom Island using isotope and trace element analysis: a new insight into Lapita interaction in the Bismarck Archipelago. Journal of Archaeological Science, 37, 605-613.

Slapcinsky, J. (2005) Six new species of Paryphantopsis (Gastropoda: Pulmonata: Charopidae) from the Papuan Peninsula of New Guinea. The Nautilus, 120, 119-130.

Slapcinsky, J. (2006) Paryphantopsis (Gastropoda: Pulmonata: Charopidae) from the Louisade Archipelago of New Guinea. The Nautilus, 120, 119-130.

Slapcinsky, J. \& Lasley, R. (2007) Three new species of Paryphantopsis (Gastropoda: Pulmonata: Charopidae) from the
Nakani Mountains, New Britain, Papua New Guinea. The Nautilus, 121, 182-190.

Specht, J. (2007) Small islands in the big picture: the formative period of Lapita in the Bismarck Archipelago. Oceanic explorations: Lapita and western Pacific settlement (ed. by C. Sand and S.P. Connaughton), pp. 51-70. The Australian National University E Press, Canberra.

Summerhayes, G.R. (2001) Defining the chronology of Lapita in the Bismarck Archipelago. The archaeology of Lapita dispersal in Oceania (ed. by G.R. Clark, A.J. Anderson and T. Vunidilo), pp. 25-38. Pandanus Books, Canberra.

Templeton, A.R., Crandall, K.A. \& Sing, C.F. (1992) A cladistic analysis of phenotypic associations with haplotypes inferred from restriction endonuclease mapping and DNA sequence data. III. Cladogram estimation. Genetics, 132, 619-633.

Vagvolgyi, J. (1976) Body size, aerial dispersal, and origin of the Pacific land snail fauna. Systematic Zoology, 24, 465488.

Voris, H.K. (2000) Maps of Pleistocene sea levels in Southeast Asia: shorelines, river systems and time durations. Journal of Biogeography, 27, 1153-1167.

Weisler, M.I. (1999) The antiquity of aroid pit agriculture and significance of buried A horizons on Pacific atolls. Geoarchaeology, 14, 621-654.

Weisler, M.I. (2001) Lapita rockshelters of Eloaua and Mussau islands. Lapita and its transformations in Near Oceania (ed. by P.V. Kirch), pp. 146-161. Contributions of the Archaeological Research Facility, No. 59. University of California, Berkeley, CA.

\section{BIOSKETCHES}

Diarmaid Ó Foighil is a curator at the University of Michigan's Museum of Zoology.

Taehwan Lee is a collections coordinator and research scientist at the same institution. They both have broad interests in molluscan systematics and evolution that include partulid tree snail conservation and biogeography.

John Slapcinsky is a collection coordinator at the Florida Museum of Natural History. He studies terrestrial molluscan diversity and has expertise in Papua New Guinea land snails.

Editor: Malte Ebach 